\title{
Jak „działa” wiersz? O składni zdania awangardowego
}

\author{
Joanna Orska
}

\begin{abstract}
Tekst powstał w ramach grantu „Nauka chodzenia”. Świadomość późnonowoczesna $w$ metapoetyckich wypowiedziach przedstawicieli polskiej neoawangardy lat 60. i 70. XX wieku (nr rej. 11H 130651 82).
\end{abstract}

\section{Potrójna delimitacja wiersza wolnego}

Wiersz awangardowy, w formule wypracowanej przede wszystkim przez Awangardę Krakowską w programach poetyckich Przybosia i Peipera, w polskiej wersologii był tradycyjnie związany z lekturą strukturalistyczną. Na taką właśnie tradycję wskazuje kanoniczne do tej pory opracowanie wersyfikacji wiersza wolnego, przygotowane przez Dorotę Urbańską ${ }^{1}$. Przypomnę, że klasyfikacja wiersza wolnego w propozycji Urbańskiej zasadza się na mocnej opozycji wiersza składniowego i askładniowego z kryterium długości linijki wyznaczanej arbitralną decyzją autora. Wiersz wolny w ten sposób to tekst sygnalizujący swoją poetyckość odbiorcy przede wszystkim w cichym czytaniu, we wzrokowej lekturze. Opozycja Urbańskiej wydaje się pochodną zdecydowanego rozdziału pomiędzy wierszem a prozą, związanego jeszcze $\mathrm{z}$ duchem awangardy historycznej i z eksponowaniem autonomiczności poetyckiego języka. Zdecydowany odpór koncepcji Urbańskiej daje na przykład Adam Dziadek w tekście Wersologia polska - kontr(o)wersje, pisząc, że strukturalizm nie poradził sobie właściwie z problemem wiersza wolnego, a typologia Urbańskiej w żaden sposób tego problemu nie rozwiązuje:

\footnotetext{
${ }^{1}$ D. Urbańska, Wiersz wolny. Próba charakterystyki systemowej, Warszawa 1995. Od zasadniczych ustaleń Urbańskiej dotyczących wiersza wolnego nie odbiegają zasadniczo tezy stawiane przez różnych badaczy, którzy podtrzymują przekonanie o podwójnej delimitacji wiersza wolnego. Adam Kulawik uzależnia ową delimitację od intonacji i pauzy, którą określa jako „fonetyczną” (Wersologia, Kraków 1999); wcześniej Maria Dłuska pisała o emocyjnej klauzuli tekstu, odnosząc się tym samym również do sfery prozodii, traktując pauzę wiersza wolnego ekspresyjnie (Próba teorii wiersza polskiego, Warszawa 1962). Propozycja Aleksandry Okopień-Sławińskiej skłaniała się podobnie ku podwójnej delimitacji, odnosząc się przy tym głównie do poetyki wiersza Przybosia. Wynikała również z prozodyjnego aspektu poetyckiej linijki, a delimitacja wersu wchodziła w rezonans z głosową interpretacją wiersza, poprzez deklamację uzasadniającego znaczenia takich a nie innych decyzji składniowo-wersowych, jedocześnie uzależniając długość wersu jako wynik arbitralnej decyzji autora (np. Wiersz awangardowy, „Pamiętnik Literacki” 1965, nr 2). Por. także nowsze studium Wiersz wolny: geneza i ewolucja do 1939 roku, red. L. Pszczołowska, D. Urbańska.
} 
Trudności z opisem tego typu wiersza wiąże się oczywiście z nieobecnością regularnej miary wersowej, ale czy w obliczu jej nieobecności można powiedzieć, że ten typ wiersza jest pozbawiony rytmu - w żaden sposób uczynić się tego nie $\mathrm{da}^{2}$.

Według Dziadka system przedstawiony przez badaczkę nie daje się odnieść do poezji najnowszej dlatego, że „ogranicza się głównie do kwestii składniowych”, wnosi więc niewiele do badań nad generowaniem znaczeń w „tekstach poetyckich”. Wraz z pojawieniem się wiersza wolnego zanikają wprawdzie regularne kody metryczne, nie oznacza to jednak, że ginie z nimi także rytm jako istotny czynnik wierszotwórczy: „Jest on w końcu zawsze obecny w dziele literackim, bez względu na to, czy mamy do czynienia z poezją czy prozą"3. Nie zgodziłabym się $\mathrm{z}$ twardym stanowiskiem Dziadka w sprawie składni wiersza wolnego, choć rozumiem intencję badacza kierującego uwagę czytelnika na antropologiczne i somatyczno-estetyczne znaczenia rytmu, dyskutowane m.in. w Anthropologie historique du langage Henriego Meschonnica. Dziadek puentuje przy tym swoje rozważania ważną z mojego punktu widzenia kwestią: to zacieranie granicy pomiędzy prozą a poezją stało się zasadniczym czynnikiem wypierającym tradycyjne metrum z roli zasadniczego czynnika wierszotwórczego. Uwaga twórców awangardowych była, jak wiadomo, skupiona na intonacji związanej z rytmem zwykłego zdania. Znaczenia takiego zdania - jak chcę później ukazać - fundowane również poprzez zabiegi związane ze składnią uwolnioną ze swoich logiczno-semantycznych zobowiązań wobec normatywnego zdaniowego porządku prozy - stały się równie istotnym czynnikiem decydującym o poetyckości tekstu awangardowego. W podobny sposób jak Dziadek, choć wcześniej i inaczej dyskutując z koncepcją Urbańskiej, podejmował tę problematykę Witold Sadowski w pracy Wiersz wolny jako tekst graficzny. Według Sadowskiego na wiersz możemy narzucić nawet dwie siatki rytmicznych uporządkowań jednocześnie, co w efekcie daje nam możliwość aż poczwórnej delimitacji wiersza wolnego. Nie uprzedzajmy jednak faktów.

W trybie mocnych, dwójkowych przeciwstawien teorię wiersza wolnego wypracowywali przed Urbańską między innymi Aleksandra Okopień-Sławińska i Janusz Sławiński, do których należą najważniejsze, wczesne wypowiedzi dotyczące składni wiersza awangardowego. Zasadniczym czynnikiem decydującym o poetyckości wersu pozostawało u tych badaczy wzmożenie jej sygnałów na innych niż metryczna płaszczyznach. W teoriach Sławińskiej i Sławińskiego rola składni w odniesieniu do długości linijki pozostaje uwzględniona, ale nie jest równie mocno, co u Urbańskiej eksponowana jako zasadniczy czynnik wierszotwórczy ${ }^{4}$. Wszystkie formuły wersologiczne, związane z podwójną delimitacją wersu w wierszu wolnym, są w gruncie rzeczy sobie bardzo bliskie i wiążą się z tekstem rozumianym jako tekst literacki w porządku strukturalnym. Można określić ten porządek roboczo jako „płaski”, dwuwymiarowy, typowy dla tekstu funkcjonującego na papierze, co jest widoczne zwłaszcza w koncepcji Urbańskiej - i co ta ostatnia otwarcie

\footnotetext{
${ }^{2}$ A. Dziadek, Wersologia polska - kontr(o)wersje, [w:]: Strukturalizm w Europie Środkowej i Wschodniej. Wizje i rewizje, red. W. Bolecki, D. Ulicka, Warszawa 2012, s. 382.

${ }^{3}$ Tamże, s. 383.

${ }^{4}$ Wiersz Przybosia wydaje się więc znaczyć w pełni, znajdować swoje konstrukcyjne uzasadnienie dopiero, kiedy jest przeczytany na głos - zinterpretowany głosowo przez artystę: „Stwarza to niezwykłe dla prozy efekty intonacyjne, skłania do zawieszania głosu w momentach nieoczekiwanych, a przezwyciężając utarte nawyki intonacyjnej łączliwości i rozdzielności, ściera z utworu piętno powszedniości i automatyzacji" (A. OkopieńSławińska, Wiersz awangardowy dwudziestolecia międzywojennego (postawy, granice, możliwości), „Pamiętnik Literacki" 1965, z. 2, s. 438).
} 
przyznaje. W jakimś sensie staranie przełamania takiej „płaskiej” (linearnej przy tym) konwencji funkcjonowania wersu, a także sposobu rozumienia towarzyszących im figur składniowych, stanowi wspominana próba Witolda Sadowskiego, w której autor usiłuje rozluźnić ciasny gorset podwójnej delimitacji. Sadowski w swojej pracy, odnosząc się w dalszym ciągu do strukturalistycznej wyjściowo tradycji, stwierdza, że kwestia podwójnej delimitacji wiersza wolnego jest nie do utrzymania - przede wszystkim w związku z wynikającą także z pracy Urbańskiej koniecznością reinterpretacji zapisu graficznego wersu. Jeszcze międzywojenne badania pokazują możliwość stosowania dwóch systemów delimitujących wers jednocześnie, polegającą na „włączeniu metrum do wiersza wolnego"s. Sadowski mówi więc o potrójnej, a nawet poczwórnej w końcu zasadzie delimitacyjnej wiersza wolnego. Poza „płaski” i linearny układ tekstu zapisanego na stronie wydrukowanego papieru, do którego stylistycznych i wersyfikacyjnych właściwości odnosili się strukturaliści, Sadowski wychodzi w kierunku (ciągle) „płaskiego” rysunku:

[...] silny graficzny podział tekstu na odcinki poziome i pionowe, grupujący wersy nie tyle w strofy, ile w bloki, stał się właściwy co najmniej dla kilku utworów o tematyce architektonicznej. [...] Można się domyślać wspólnej wrażliwości, która cechowała tych poetów w latach pięćdziesiątych i kazała widzieć w wierszu wolnym możliwość naśladowania kubatury architektonicznej6.

Pytanie, jakie chciałam w moich wersyfikacyjnych rozważaniach postawić, w punkcie wyjścia dotyczy nie tylko i nie tyle składni zdania awangardowego. Zasadza się ono raczej na próbie zmierzenia się z płaskością kartki papieru - z czym powiązana byłaby intuicja możliwej przestrzenności i ruchomości układów składniowych - której próbowali dopracować się awangardziści, stawiając wobec swoich wierszy postulaty „budowy”. Taką możliwość stworzyć może retoryka, jeżeli w większym stopniu retoryczne przesłanki kompozycji dzieła (chcę je rozumieć raczej jako „działanie”), wykorzystane zostaną nie tyle jako narzędzia opisujące stylistyczne aspekty tekstu, ale jako systemat twórczych dyspozycji, powiązanych z odbiorem, traktowanym w kategoriach actio - wykonywania tekstu artystycznego. Tekst poetycki w takim ujęciu byłby „notacją" - na podobieństwo zapisu nutowego w muzyce - jego „wykonanie” polegałoby zaś na „mimetycznym” powtórzeniu czynności twórczych autora.

\section{Retoryczna koncepcja wiersza wolnego jako budowy-wykonywania dzieła}

Tradycja retoryczna łączy zapisany tekst poetycki, jako tekst przeznaczony do wygłoszenia przede wszystkim, z muzyką i tańcem (ze względu na rytm) - dzieląc przy tym rozmaite sztuki według kryterium odnoszenia znaków mimetycznych do poszczególnych zmysłów. W ten sposób poezja powiązana została ze zmysłem słuchu, malowanie obrazów ze wzrokiem, kucharstwo ze smakiem, a komponowanie perfum $z$ węchem (o ile te działania służą celom mimetycznym), dotyk zaś w końcu ze sztukami wizualnymi, architekturą - i znowu tańcem. Po to, żeby zrozumieć ten szczególny aspekt retoryki, który moim zdaniem zostaje uwolniony dzięki zabiegom związanym ze składnią wiersza (stanowiącą szczególną dyspozycyjno-kompozycyjną notację), należałoby uwzględnić jeszcze jeden aspekt, na etapie retoryki starożytnej nie uwzględniany - a mianowicie ruch, łączący poezję z tańcem, w sensie powtarzania

\footnotetext{
${ }^{5}$ W. Sadowski, Wiersz wolny jako tekst graficzny, Kraków 2004, s. 201.

${ }^{6}$ Tamże, s. 203.
} 
wykonywanych, przepisanych regułą kroków. Konstruowaniu swego rodzaju wyobrażonych, wspólnotowych rzeczywistości, stanowiących system punktów orientujących nas w przestrzeni (jego mapa wytwarza się w mózgu, kiedy nabywamy zdolności ruchowych), odpowiadałaby konieczność komponowania retoryczno-syntaktycznych układów, stanowiących zapis specyficznie rozumianego doświadczenia twórczego. Można by je dookreślić jako doświadczenie praktyki twórczej: jednocześnie poznawcze i funkcjonujące jako doświadczenie rzemiosła (tego, co wyuczone, czego znajomość zarówno twórcę, jak i doświadczonego odbiorcę sytuuje $\mathrm{w}$ roli eksperta). Udział w poetyckich praktykach prowadziłby w taki sposób, poprzez system „orientacyjnych" twórczych zaleceń, do re-konstruowania wspólnotowo rozumianego doświadczenia świata. W sferze dyspozycyjno-kompozycyjnych zaleceń co do wykonania, odbioru „budowy” wiersza wolnego, możemy tak rozumiane notacje potraktować jako swego rodzaju uwewnętrznione symulacje ruchu.

Projektom awangardowej „budowy” świata zawsze towarzyszyła utopia „zmieniania” rzeczywistości. Ten fakt, który możemy widzieć jako swego rodzaju „politykowanie” tekstem, powoduje, że wiersz awangardowy tym łatwiej przystosować do kategorii właściwych dla retoryki. Wiersz awangardowy, ze względu na swoją inwencyjność, odbieganie od odbiorczych tradycji, jest zawsze szeregiem dyspozycji od-twórczych, kierowanych pod adresem odbiorcy, pozostającego w przypadku historycznych awangard zawsze w pozycji ucznia, adepta czy też praktykanta w warsztacie poety-rzemieślnika. Słowo „dyspozycja” pozostaje dla mnie na tym etapie rozważań szczególnie ważne, odsyłając nas do „dyspozycyjnych” działań retoryki, która - jako dziedzina w bezsporny sposób powiązana z performatywnie rozumianymi narzędziami komunikacji i z prerogatywą perswazji, edukowania odbiorców: kształtowania „wspólnego” świata za pomocą nowych słów - znacznie lepiej nadaje się do rozmowy o awangardowej poezji niż klasycznie rozumiana stylistyka. Retoryka formułuje z powodzeniem wiele dylematów teoretycznych, uniemożliwiających w gruncie rzeczy sprawną, pozbawioną sprzeczności rozmowę o interwencjonizmie awangardowej literatury ${ }^{7}$. Standardem związanym z nowoczesnymi koncepcjami poetyki jest przejmowanie całego arsenału figur retorycznych, traktowanych jednak po prostu jako figury stylistyczne - na specyficznych warunkach i nie zawsze w pełni w odniesieniu do kontekstu, z jakiego się wywodzą. Z perspektywy stylistyki stosowanej we wszystkich właściwie obecnie funkcjonujących podręcznikach poetyki, liczą się przede wszystkim figury przynależące do sfery elokucji, do grupy tropów - nie uwzględnia się elementów łączących te

\footnotetext{
${ }^{7}$ Marek Skwara na wstępie do antologii przekładów „Pamiętnika Literackiego”, zatytułowanej Retoryka, zwraca uwagę na zasadnicze dla nowoczesnej i ponowoczesnej refleksji nad retoryką zredukowanie jej tradycyjnego rozumienia do sfery figur retorycznych (tropów, figur słów i myśli) wobec jej tradycyjnego zakresu: inventio, dispositio, elocutio, memoria - związanego z pamięcią i zapamiętywaniem, mnemotechnikami towarzyszącymi sztuce wymowy i pronuntiatio - $\mathrm{z}$ aspektem rzeczywistego odegrania tekstu: actio, wygłoszeniem. Powiedzieć można, że to operowanie wyłącznie na figurach, stanowiących element elocutio, dostrzegalne jest, jak krytycznie zarazem zauważa Skwara, nie tylko w rozmaitych próbach adaptowania retoryki na rzecz nowych, ponowoczesnych interpretacji tekstów kultury czy historii (jak u de Mana czy Derridy, czy z innej perspektywy Hydena White'a) ale całkiem po prostu, w podręcznikach stylistyki i wersyfikacji, odnoszących się wprawdzie do składni zwykłego zdania mówionego, ale nie uwzględniających dużych, „suprasegmentalnych” konsekwencji, które powinny się wiązać z rozpoznaniem jego retoryczności. Skwara stwierdza, że aplikowanie narzędzi retoryki do nowoczesnych nauk humanistycznych zawsze oddaje jej sprawiedliwość nie w pełni, zawsze w pewnym ograniczeniu, a taki stan rzeczy wynika z upadku jej autorytetu. Przywołuje przy tym opinie badaczy (np. Todorowa), którzy twierdzą, że retoryka utraciła swoje znaczenie w romantyzmie, kiedy zanikła kluczowa dla dyspozycyjnej płaszczyzny dychotomia naturalne - sztuczne. Jak komentował ten stan kryzysu Chaim Perelman: „Jeśli figury retoryczne nie są włączone do retoryki pojmowanej jako sztuka perswazji i przekonywania, przestają być figurami retorycznymi, a stają się ozdobami dotyczącymi tylko formy mowy". Cyt. za: Retoryka (Tematy teoretycznoliterackie, archiwum przekładów „Pamiętnika Literackiego”), red. i wstęp M. Skwara, Gdańsk 2008, s. 18.
} 
figury z innymi sferami i przesłankami retoryki. Wobec podstawowego kryterium skończonego artystycznie dzieła (zgodnie z którym płaszczyzny inwencji i dyspozycji pozostają ukryte, a kwestii pamięci i wymowy w ogóle się nie porusza); wobec całej palety możliwości, jakie dają środki retoryczne, w wyraźny sposób faworyzowane tropy, oparte na związkach pojedynczych słów, skupiają uwagę odbiorcy całkowicie na semantycznym wymiarze tekstu i na jego wieloznaczności. Ta wieloznaczność formułowana jest wobec językowej normy i wobec słownika (więc języka rozumianego jako zbiór leksemów). Tropy pełnią w stylistyce wiodącą rolę - przed figurami słów złożonych, do których należą środki składniowe, i przed figurami myśli, o których w ogóle mówi się bardzo rzadko. Powiedzieć można, że właśnie w związku z ograniczaniem znaczenia elementów tekstu, których rola wynika z wiązania wypowiedzi w znaczącą całość i prowadzi nas ku zagadnieniom kompozycji, związanej bardziej bezpośrednio ze sferą dispositio, elementy „dyspozycji twórczej” można upodrzędnić wobec sfery elokucji tym łatwiej. Figury słów, czyli figury składniowe, w najbardziej popularnych podręcznikach poetyki, służących jako materiał do nauczania na uczelniach wyższych i w liceach (Kulawika, Korwin-Piotrowskiej czy Handkego), są uwzględniane w podstawowym stopniu, przy czym nacisk kładzie się na takie, które podkreślają rytmizacyjny, powtórzeniowy, refreniczny czy zmierzający ku paralelizmowi aspekt składni, co wynika z dominanty wersu jako krótkiego odcinka rytmu czy znaczenia, traktowanego jako czynnik wierszotwórczy na zasadzie wyłączności. W ten sposób zakres działania figur słów ograniczany jest „przywiązaniem” składni do wersu. Wiersz wolny tymczasem powinien wyzwolić nie tylko rytm, ale także składnię. Efektem pomijania retoryczno-składniowego aspektu, jakie niosą ze sobą figury słów powiązanych, jest doraźne, na zasadzie erudycyjnego wyjątku tylko, przywoływanie takich elementów wiązań zdaniowych, jakie przynoszą wszelkie diplozy, zeugmy (z jej ważną pochodną syllepsis), anastrofy, hyperbatony, chiazmy, prolepsy, paralepsy, metalepsy - nie mówiąc o figurach myśli, jak aposjopeza czy correctio. Analiza i interpretacja wiersza zazwyczaj sprowadza się do deszyfracji znaczeń (metafory, metonimii, synekdochy), traktowanych jako tropy odnoszone do znaczeń językowego uzusu lub jako wielkie figury semantyczne. Sam proces lektury w punkcie dojścia doprowadzić musi do „słownikowego” unieruchomienia znaczeń wiersza: do objaśnienia poetyckiej wieloznaczności nowych związków słów. Tekst podwójnie delimitowany nic nie oznacza samą swoją konstrukcją (ze względu na kompozycję odnoszącą się do sfery konstrukcyjnych decyzji autora) - nic, prócz tego, że jest właśnie wierszem. Ten antyretoryczny efekt interpretacyjny pokazuje dobrze sposób, w jaki uporządkowana zostaje kwestia składni zdania awangardowego w najsłynniejszej z rozpraw o Awangardzie Krakowskiej Janusza Sławińskiego ${ }^{8}$. Autor Koncepcji języka awangardy, wyliczając efekty polisemii osiągane poprzez manipulacje składniowe, skupia się więc na paronomazjach, neologizmach tworzonych poprzez aktualizowanie wieloznaczności morfemów, pisze bardzo ciekawie o przekładaniu ope-

\footnotetext{
${ }^{8}$ Operacja zdaniotwórcza - jak w Koncepcji języka poetyckiego awangardy dowodził Sławiński - była dla zwrotniczan podstawową jednostką działania poetyckiego; ona dopiero pozwalała traktować znaczenie w kategoriach funkcji, dzięki której możliwe było takie ustosunkowanie wzajemne słów, „by ich spotkanie stało się «zdarzeniem» językowym o doniosłości niezależnej od zdarzeń rozgrywających się poza sekwencją wyrazową". J. Sławiński, Koncepcja języka poetyckiego Awangardy Krakowskiej, Kraków 1998, s. 91. Wspomniane przez Sławińskiego „akcje” czy „zdarzenia”, rozgrywające się wśród znaków, okazują się przy tym wynikiem asocjacji właściwej dla metafory rozumianej dość statycznie: jako zbliżenie dwóch nieprzystających do siebie elementów - nie zaś jako wynik przyrastania informacji w zdaniu rozumianym jako struktura tematycznorematyczna wiersza wolnego. Pisałam o tym m.in. w tekście Życie słowa. Składnia zdania (post)awangardowego, który ukaże się w tomie Przyboś dzisiaj, pod red. Zenona Ożoga, Janusza Pasterskiego i Magdaleny Rabizo-Birek (Rzeszów 2017).
} 
racji słowotwórczych na szereg składniowy w eufonicznych ciągach zdaniowych, o fałszywej homonimiczności związanej z grupowaniem podobnych brzmieniowo, a odrębnych znaczeniowo wyrazów, czy o wypełnianiu odmiennym materiałem słownym zastanych szablonów syntaktycznych. Bardzo krótko wypowiada się jednak o słynnym zdaniu rozkwitającym (zdanie Peipera - w odróżnieniu od eliptycznego zdania Przybosia - traktuje jako „peryfrastyczne", tzn. mocno osadzone w anegdotycznym kontekście, co za tym idzie, nie tak płodne, jeżeli chodzi o pożądane, polisemiczne efekty). O zeugmie pisze Sławiński tylko na marginesie, w ogóle nie wspomina o konstrukcjach sylleptycznych, do wszelkiego rodzaju elips, kontrakcji jako najczęściej wykorzystywanych przez awangardową składnię figur, odnosi się na zasadzie zbiorczej, widząc w nich narzędzie umożliwiające Przybosiowi odejście od Peiperowskich rygorów awangardowego „rozwijającego się” wiersza quasi-zdaniowego. Anakoluty nie są więc na przykład twórczymi błędami w składni, ale błędami umożliwiającymi wieloznaczność. Tej „nazewniczej” tendencji, podporządkowanej słownikowi rozumianemu jako zbiór leksemów, towarzyszy ukazywanie wiersza jako gotowego, poniekąd zastygłego w jednoczesności olśniewających skojarzeń, więc także statycznego obrazu pewnej rzeczywistości.

\section{Wers i wiersz. Trzy płaszczyzny delimitacyjne wiersza wolnego}

W jaki sposób potrójna, a nawet poczwórna delimitacja wiersza wolnego, proponowana przez Witolda Sadowskiego, zasadniczo zmienia „słownikowo”-tropiczne, stylistyczne uwarunkowania lektury tekstu poetyckiego? W wierszu wolnym w koncepcji Urbańskiej, a także wcześniej Okopień-Sławińskiej, intonacja zostaje w jednoznaczny sposób powiązana ze składnią zwykłego zdania - może więc poddawać się modulowaniu deklamacyjnemu ze względu na rozmiar linijki lub być uzależniona od logicznych związków składniowych, które linijkę przekraczają. Bez względu na to, czy w lekturze poddamy się determinancie wersu, czy składni, intonację będziemy rozumieć jednoznacznie, jako zależną od naturalnego rytmu zdania. W wierszu wolnym, jak zauważył Sadowski, pojawiają się jednak często jeszcze inne rytmy, także okazjonalnie staje się on wierszem włączającym założenia regularnego metrum, często na zasadzie swoistego cytatu tradycji (autor Wiersza wolnego jako tekstu graficznego przywołuje przykład wierszy Herberta). Spostrzeżenie ich obecności przynosi odmienną jeszcze realizację prozodyjnej formuły wiersza, który może nawet odnosić się jednocześnie do dwóch systemów wierszowych (wiersza regulowanego metrem i intonacją) - dzięki czemu wiersz będzie konstytuował swoje poetyckie znaczenia jednocześnie na dwóch płaszczyznach. W ten sposób dział odpowiadający jednostce wersowej ze względu na metrum może wypaść w środku wersu, utworzonego arbitralnie lub z przyczyn związanych z operacjami na składni, a powiązanymi $z$ intonacją. Wiersz wobec tego można przeczytać na kilka sposobów - zgodnie z intonacją związaną z segmentacją tekstu, zgodnie $\mathrm{z}$ intonacją zdania przekraczającego granicę linijki i zgodnie z rytmem metrum - to zabieg oczywisty dla wielu wierszy Piotra Sommera, który często rytmiką manipuluje, oscylując pomiędzy rytmem zwykłego zdania i metrum, nawiązującym do regularnego bądź tonicznym. Uwieloznacznienie wiersza w kategoriach intonacji powoduje, że mamy tu do czynienia z całą sferą czytelniczych wyborów, których dokonywanie modyfikuje też na wiele sposobów znaczenia tekstu. Uwypuklenie znaczenia poetyckiego sfery intonacji „wypycha” problemy składniowe, związane przez Urbańską z porządkiem „płaskim”, wiersza zapisanego na kartce, w przestrzeń odnoszącą się do sytuacji „wymowy” (enuntiatio) zanotowanego tekstu poetyckiego. 
Czy taki, potrójnie czy poczwórnie delimitowany wiersz można już nazwać „przestrzennym”? Powiedzmy na razie, że tekst uwzględniający jednocześnie kilka kryteriów intonacji wykracza poza ograniczenia wersu w kierunku, który jest powiązany także ze zobowiązaniami retoryki, a nie tylko stylistyki poetyckiej - więc w kierunku głosu. Wiersz wolny, uzależniony jest od czynników związanych z wymową, deklamacją, stylem wygłoszenia - w zależności od wyboru stylu lektury. Rozmaite rozumienia intonacji powodują także, że całą sferę zapisu zaczynamy traktować jako sferę "dyspozycji” - kompozycji do wykonania - nie tylko zaś jako płaszczyznę elokucji, ściśle określonego zapisu. Czytelnik ma wybór, czy potraktuje wiersz jako przede wszystkim odnoszący się do modelu regularnej rytmiki, czy uwzględni przede wszystkim kontur podzielonego na linijki zdania, czy też uzna oba te kryteria za równoważne. $Z$ punktu widzenia wypowiedzi dotyczących wersyfikacji Adama Ważyka odziedziczona po strukturalizmie, a zasadnicza dziś, jeżeli chodzi o reguły wyodrębniania wiersza wolnego, podwójna delimitacja wersu, stanowi zupełnie niepotrzebne ograniczenie. W odróżnieniu od poetyki wypracowanej przez Awangardę Krakowską Ważyk nie akcentował tego elementu wersyfikacji, który byłby związany ze składnią zwykłego zdania jako przeciwstawianej wobec rytmu wynikającego $z$ metrum z jednej strony i wobec prozy z drugiej. Dla Ważyka rytmy wiążące się z tradycją wiersza polskiego stanowiły zbyt istotny czynnik wierszotwórczy, żeby można było z niego po prostu zrezygnować - między innymi dlatego, że autor Amfiona, jeśli chodzi o wiersze, bardzo dużą wagę przywiązywał do procedur ich zapamiętywania, czyli do mnemotechniki. Jak pisał w Eseju o wierszu:

Poezja chce być albo zapamiętana dosłownie albo czytana wielokrotnie [...] Poeta marzy o tym, aby ten sam czytelnik wracał do jego wierszy. Zależy mu nie tyle na liczbie czytelników, ile na ich wierności. Informacja, którą przekazuje, powinna być często wznawiana, jeżeli nie może być trwała. [...] Ubytek informacji jest odpowiednikiem wzrastania entropii. Organizacja wiersza, powołana do opóźnienia tego procesu, sama mu również podlega ${ }^{9}$.

Ważyk nie zastanawia się nad tym, dlaczego właściwie poezja „chce być zapamiętana” - nie akcentuje w żaden sposób retorycznych funkcji mnemotechniki i powiązanych z nią zabiegów służących zapamiętywaniu tekstu. Jednak tradycyjne rytmy wiersza polskiego (wypracowane przez Kochanowskiego, Trembeckiego, Mickiewicza) wyznaczają w jego wersologicznych interpretacjach funkcję normy szeroko rozumianej, utrwalanej, zapamiętywanej więc właśnie przez wielokrotne powtarzanie. Ważykowy „werlibryzm” nie ma sensu, jeżeli nie kształtujemy wiersza nowego, wolnego, nie pamiętając o dawnym metrum. Tak też poeta „werlibrysta”, kierując się interesami zwykłego zdania, bliskiego prozie, jako zasadniczej jednostki kształtującej wers, wprowadza w swoje struktury rozmaite miary wiersza związane z tradycją - na zasadzie swego rodzaju flirtu wiersza wolnego z regularnym systemem, który w punkcie wyjścia stanowił odrzucaną przez awangardę formułę poetyckości ${ }^{10}$. Potrójna delimitacja linijki, budowanie wiersza w swego rodzaju napięciu pomiędzy rozmaitymi tendencjami wersyfikacyjnymi (metrum, składnia, arbitralnie rozumiana długość wersu wiersza wolnego), stanowiła oczywistość dla autora Amfiona, ponieważ w swoich pracach wersologicznych wprowadzał „rzemieślnicze” kryteria delimitacji. Ważykowy system wersyfikacyjny wydaje się wykraczać poza płaszczyznę

\footnotetext{
${ }^{9}$ Tamże, s. 24.

${ }^{10} \mathrm{~A}$. Ważyk, O wierszu wolnym, [w:] tegoż, Amfion. Rozważania nad wierszem polskim, Warszawa 1983.
} 
konstytuowaną przez tradycyjnie rozumiany wers wiersza wolnego i decydujące o jego poetyckości, stosowane w nim środki stylistyczne, uwięzione poprzez strukturalistyczną tradycję w wersie zapisanym na kartce i w słowniku, znowu ku wygłoszeniu. Ku actio powiązanym ze sferą pronuntiatio, ale także ku memoria. Rytmowi i powtórzeniom powiązanym z regularną wersyfikacją przywrócona zostaje ich tak perswazyjna, jak i upamiętniająca poetycki gest funkcja - niekonieczna za perspektywy kultury druku, ale mająca też głęboko intymny wymiar, związany z odbiorczym oswajaniem tekstu literackiego dzięki temu, co już znane.

To jednak nie wszystkie możliwości ożywienia reguł wierszotwórczych poprzez aplikowanie do wiersza podejścia odbiorczego głęboko powiązanego z retoryką. Zabiegi składniowe, które próbuję pokazać w mojej pracy, wprowadzają jeszcze jeden wymiar delimitacyjny, jeszcze jeden system składniowych cięć w obręb utworu, oparty w całości na figurach słowa, a raczej na wierszotwórczym potencjale błędu składniowego. Zabiegi typowe dla awangardowej składni umożliwiają właśnie wspominane na początku „budowanie” wiersza; składnia rozumiana jest przeze mnie nie tyle w unieruchomionych kategoriach figur słowa, powiązanych $\mathrm{z}$ „ozdobnością”. Uruchamiając konstrukcyjny potencjał składni, uniezależniając ją od wersu i czyniąc z niej jeszcze jeden element delimitujący jednostki znaczenia w wierszu (rozbijając więc wersy na zdania poetyckiej prozy), uwalniamy jednostki składniowe poszczególnych wersów z wiążących je funkcji współtworzenia porządku wersowego, który staje się znowu porządkiem rozumianym jako dyspozycja do wyboru. Zdania wiersza wolnego pozostają jednak wyzwolone także z konieczności tworzenia normatywnie rozumianego porządku logiczno-semantycznego poetyckich zdań - przestają bowiem funkcjonować jako składniowa norma wobec arbitralnie rozumianego porządku wersu wiersza wolnego. Działy składniowe wewnątrz wersu wprowadzają w ten sposób (jeszcze) dodatkowe pauzy i łączenia, umożliwiając konstruowanie poetyckich znaczeń dzięki potencjałowi tych wiązań; składniowe, konstrukcyjne działanie może przypominać wznoszenie budowli z cegiełek. Przestrzeń wiersza jest oczywiście przestrzenią wyobrażoną; jeżeli jednak jej układ potraktujemy jako związany ze sferą dyspozycji twórczych, rozumianych także jako kompozycyjne dyspozycje pod adresem czytelnika, wiersz stanie się budowlą - twórczym zadaniem do wykonania. Tak jak według Ważyka wiersz wolny pozostawał w rzeczywistości częściowo wolny, częściowo wiązany, podobnie tutaj działania na składni pozostają rozpięte pomiędzy składnią prawidłowego wypowiedzenia i błędem składniowym.

Składniowa teoria wiersza awangardowego niesie ze sobą ściśle wynikające z ducha retoryki konsekwencje; po to jednak, aby składniowa teoria wiersza awangardowego była możliwa, musi najpierw zostać postawiona teza, że nie ma wierszy askładniowych. Założenie askładniowości wiersza wiąże się z przyjęciem podziału na wersy jako prymarnej wierszotwórczej zasady. Istnieją jednak przekształcenia składniowe, zakładające odejście od normatywnej składni, które zyskują semantyczne nacechowanie i stają się elementem poetyckości tekstu, choć mogłyby nim być zarówno w wierszu, jak i w prozie. Na takiej zasadzie funkcjonować może proza poetycka. Podobnie jak w przypadku potrójnej czy poczwórnej delimitacji wiersza będziemy rozpatrywać jako środki wierszotwórcze rytm/metrum i składnię/intonację odnoszoną do arbitralnie rozumianej długości wersu, tak w przypadku wiersza, który gra całą swoją składniową konstrukcją, poza wymienionymi czynnikami znacząca dla czytelnika powinna stać się długość wersu zderzana z długością całego zdania, czy też całego wiersza, który w naszym przypadku będzie postrzegany jako okres retoryczny. 


\section{Pożytki z retorycznej teorii wiersza}

Szczególnie przydatna dla ukazania istotnego potencjału interpretacyjnego, jaki może płynąć z poszerzenia puli narzędzi przyswajanych z retoryki do poetyki, jest oczywiście klasyczna praca Heinricha Lausberga Retoryka literacka. Podstawy wiedzy o literaturze. Polskie podręczniki retoryki (Retoryka opisowa Ziomka, Zarys podstaw retoryki Korolki) powiązane są bezpośrednio ze sztuką wymowy, podczas gdy Lausberg za punkt wyjścia swoich rozważań przyjmuje punkty, w jakich interesy wymowy i literatury stają się zbieżne, nakładają się bądź przecinają. Interesować mnie w tym przypadku będą przede wszystkim zbiegi związane z przekształceniami „słów połączonych” (w mniejszym stopniu zaś pojedynczych, więc tropów). Retoryka tradycyjnie bywa przekładana na kategorie dzieła literackiego. $Z$ awangardowego punktu widzenia najważniejszy byłby ten jej element, który wskazuje na praktyczny, czynnościowy charakter retoryki. Odniosę się w dalszej części tekstu jedynie do zabiegów wykonywanych na „słowach połączonych”, związanych z „ozdobnością”, nie poprawnością i jasnością wymowy (ornatus - obok literaria i claritas). Retoryka - jako sztuka kompozycji większych układów zdaniowych - i jako praktyka polegająca na stosowaniu określonych technik w wymowie pomija (choć zarazem także i dokumentuje) rozdział przyjmowany za Etykq nikomachejskq Arystotelesa jako nieprzekraczalny - rozdział poiesis i praxis ${ }^{11}$. Czyni to kładąc nacisk na wykonywanie, ćwiczenie, praktykowanie reguł dla osiągnięcia określonego efektu; stawia więc odbiorcę sztuki w sytuacji adepta, wykonującego określone poprzez sztukę, poiesis, reguły, dla osiągnięcia efektu, który wprawdzie jest „praktyczny” (jest praktykowaniem sztuki), ale nie staje się wyłącznie 'przedmiotem', takim jak na przykład but tworzony zgodnie z regułami sztuki szewskiej. Sztuka (techne, ars) według definicji, jaką można by tu roboczo przyjąć za znanym podręcznikiem Lausberga, zbierającym i porządkującym cytaty ze wszystkich najbardziej istotnych wykładni retoryki, rozumiana jest w „czynnościowym” kontekście retoryki jako: „uporządkowany proces, który zmierza do doskonałości” ${ }^{12}$. Ów proces - jak wywodzi Lausberg - może mieć charakter naturalny, korespondować z naturalnym biegiem wydarzeń (np. rozwijanie się drzewa); może jednak zaistnieć także przez przypadek albo wskutek przemyślanego działania (techne/arte). Artystyczne działanie (epuos, opus), które nie odpowiada naturze (phisis), nie może istnieć bez jej współudziału: takiego jak np. naturalna predyspozycja jednostki do działania. Jeśli jednostce brak doświadczenia (apeiria), sztuka jest zdana na los (tiche) - po pierwsze dzieło sztuki rozwija się więc na podstawie fisis poprzez apeiria

\footnotetext{
${ }^{11}$ Etyka nikomachejska Arystotelesa jest pozycją przywoływaną przez filozofów dla podkreślenia różnicy pomiędzy grecką poiesis (tworzeniem) i praxis (działaniem, tłumaczonym też jako doświadczenie). Różnica ta wiąże się z celem działania; na tej zasadzie poiesis obejmuje wszelkie tworzenie, którego cel może zawierać się w nim samym, ale związany jest $\mathrm{z}$ tym, co zewnętrzne, w przypadku praxis zaś cel związany jest z samym działaniem, ściślej zaś z jego powodzeniem. Przynależą jednak obie do „filozofii praktycznej”, pozostając na równi pewną „trwałą dyspozycją” człowieka, według Arystotelesa rodzajem „dzielności”, a więc cnotą. Arystoteles mówi, jak przypomnę: „Owóż wszelka sztuka łączy się z powstawaniem i z wynalazczym obmyślaniem tego, by powstało coś z rzeczy, które mogą i być, i nie być, i których źródło tkwi w wytwarzającym, a nie w wytworze; bo nie są wytworami sztuki te rzeczy, które z konieczności istnieją lub powstają, ani te, które istnieją lub powstają w sposób zgodny z nakazami natury (te bowiem rzeczy mają same w sobie swe źródło). Skoro zaś tworzenie i działanie to rzeczy różne, to z konieczności sztuka podpada pod tworzenie, a nie pod działanie" (Arystoteles, Etyka nikomachejska, przeł. D. Gromska, L. Regner, W. Wróblewski, Warszawa 2002, s. 196). Z mojej retorycznej perspektywy, można dodać, że wobec dzisiejszej, kulturowej świadomości literatury, zakładanie „tworzenia” jako czegoś, co nie ma również źródła w wytworze (np. w innych dziełach lub w pamięci, choćby materiału vide tradycje wersyfikacyjne) jest nieuzasadnione; całkowicie zaś znika, jeśli potraktujemy poezję jako system dyspozycji odbiorczych przeznaczonych do „wykonania”.

${ }^{12} \mathrm{H}$. Lausberg, Retoryka literacka. Podstawy wiedzy o literaturze, przekł., oprac. i wstęp A. Gorzkowski, Bydgoszcz 2002, s.19 i n.
} 
i tiche. Każde powtórzenie tego znanego, lecz niezrozumiałego kontekstu działania prowadzi do „doświadczenia” (empeiria). W doświadczeniu (empeiria) los (tiche) wiedzie nas znaną nam drogą. Pod tym względem każde powtórzenie, które określa i potwierdza doświadczenie, jest już imitacją (mimesis). Działanie twórcze, z praktycznej konieczności postrzegane w retoryce jako nieoddzielne od odbiorczego, polega więc na odtwarzaniu czy też naśladowaniu wzorów. W retoryce imitacja, naśladowanie wzorów, jest zawsze związana z nauką i pozostaje jako taka mimesis artystycznej praktyki. Z perspektywy poezji awangardowej, której charakter wykraczał poza to, co oferuje poezji sama poetyka, rozumiana jako oddzielna od retoryki sztuka, elementami, które są wręcz konieczne do uwzględnienia pozostawałyby nie tylko memoria i pronuntiatio, ale (najpierw) inventio i dispositio pojęte jako zdolność do wynajdywania tego, czego jeszcze nie było i uwidoczniania procesu twórczego w samym zapisie nowych reguł kompozycji, tak żeby mógł być również praktykowany. Sfera dyspozycji twórczych, uwidoczniona w między innymi „składniowym” zapisie twórczego procesu, określona może zostać właśnie jako „budowanie” wiersza awangardowego. Retoryczne rozumienie procesu komunikacyjnego jest konieczne do zaaplikowania wtedy, kiedy wiersz i jego wykonanie rozumiane są jako działania, nie zaś w charakterze artystycznego przedmiotu, gotowego artefaktu.

Awangardowe dzieło, zgodnie z zasadami przeniesionymi z retoryki do poezji, to dzieło, które wypracowuje własne warunki działania - uwidaczniają się one właśnie w „notacji” sfery dispositio, rozumianej przeze mnie także jako twórcze dyspozycje odbioru - w związku z którymi wiersz jest kompozycją „do powtórzenia”. „Notacje” te utożsamiam z działaniami twórczymi związanymi ze składnią - tworzącą dłuższe niż wers okresy, umożliwiające prześledzenie strategii konstrukcyjnej autora na przestrzeni całości utworu. Dzieło awangardowe zawiera w sobie element doświadczenia twórczego, rzemieślniczego, które jest w odbiorze powtarzane, a które staje się widoczne właśnie w sferze kompozycji/dyspozycji. Uwzględniając na płaszczyźnie elocutio to, co właściwe dla dispostio, utwór imituje/zapisuje działania, które doprowadziły do jego powstania. Mogą być to działania własne autora, czy też cudze, mistrzowskie: praktykując je (wprowadzając w sferę elokucji element praktyki), naśladując i ćwicząc wzory, i sam wiersz, i jego autor zdają relacje z twórczego doświadczenia, które zostało nabyte drogą działań twórczych. Wiersz awangardowy „performuje” więc doświadczenie, stosując odpowiadające temu techniki. Jak podaje podręcznik Retoryki literackiej Lausberga, ujmując rzecz od jakby innej, bardziej retorycznej niż stylistycznej (jak powyżej) strony: „Każdej ars można nauczyć, a także nauczyć się poprzez komunikowanie reguł” (20) i „jeśli uczeń ma predyspozycje i praktykuje wyuczoną wiedzę poprzez praktyczne jej zastosowanie [...] techne (więc element poiesis - przyp. J.O.) ponownie wnika w empeiria (element praxis - przyp. J.O.), tyle że teraz empeiria jest racjonalnie oświecona przez techne" (21). Sposób, w jaki retoryka podchodzi do funkcji sztuki i potrzeb jednostki, jakie spełnia ćwiczenie przemyślanych reguł, ściśle odpowiada aktywistycznym i interwencjonistycznym tendencjom awangardy. Kenneth Burke w szkicu Tradycyjne zasady retoryki wskazuje, że retoryka ma przede wszystkim skłaniać do podejmowania określonych działań (Arystoteles, Cyceron), a także kształtować postawy (Kwintylian $)^{13}$. Odniesienie pojęcia perswazji do rozumianych etycznie postaw umożliwia stosowanie terminologii retorycznej do struktur poetyckich - jeśli rozpatrywać środki wyrazu

${ }^{13} \mathrm{~K}$. Burke, Tradycyjne zasady retoryki, przeł. K. Biskupski, [w:] Retoryka (Tematy teoretycznoliterackie, archiwum przekładów „Pamiętnika Literackiego”), s. 41. 
ze względu na zdolność komunikowania i budzenia pewnych stanów emocjonalnych, bez konieczności przynoszenia skutków praktycznych. A jednak właśnie Kwintylian awansował retorykę do rangi ośrodka całego systemu wychowawczego, przedstawiając, że doskonały mówca jest doskonałym obywatelem. Kiedy mówimy więc o performatywności retoryki, nie borykamy się z problemami teoretycznymi, jakie stawia przed nami zagadnienie performatywności literatury czy performatywności poezji; z perspektywy retoryki zapisany tekst jest przykładowym i zarazem mistrzowskim użyciem reguły, której ćwiczenie prowadzi zarówno do ich uprzytomnienia, przywołania (elokucji rozumianej tu także jako actio, wykonanie), jak i do kształtowania postaw (twórczych) poprzez owych reguł uwewnętrznienie, spojenie ich z własnym doświadczeniem. Oczywiście takie kształtowanie postaw może być rozumiane bardzo wielorako; nauczyciel reguł w poezji awangardowej może być szalonym nauczycielem-eksperymentatorem albo Rancière'owskim nauczycielem-ignorantem, korzystającym ze znajomości reguł wykształconego czytelnika. Jedno nie ulega wątpliwości, poezja awangardowa to poezja sprawcza, performatywna w tym sensie, że zawsze próbuje się w niej czegoś nas nauczyć: więc skłonić nas do bardzo ściśle określonego rodzaju twórczej imitacji. Żeby przeczytać awangardowy wiersz, musimy go poniekąd nie tyle rozumieć - co czynnie, od-twórczo naśladować.

Ostatnia już uwaga, jeżeli chodzi o pożytki płynące ze ściślejszego połączenia wiersza awangardowego ze sposobem myślenia o sztuce właściwym dla retoryki. W klasyfikacji artes, jak podaje Lausberg, uwaga koncentruje się albo na wykonywanym działaniu, albo na tym, kto owo działanie wykonuje (artifex, actor) ${ }^{14}$. Działanie ma trzy stopnie konkretności i właśnie w zależności od tego sztuki dzielą się na pojetyczne, praktyczne i teoretyczne. Sztuki pojetyczne, zakładają, jak wiadomo, umiejętności zasadzające się na wykonaniu czegoś, co „może być, albo nie być" (buta, wiersza, krytyki). A jednak zarówno wiersze, jak i utwory muzyczne (czy w końcu krytyka), wytworzone za pomocą reguł poezji czy muzyki (rozumianej jako teoria), nabierają cech „zdarzenia” (bo nie przedmiotu), kiedy wykonywane są za pomocą odpowiedniej sztuki praktycznej. Także sztuki praktyczne (performatywne) - zasadzające się na działaniu - muszą (czy też mogą) zakładać istnienie „pojetycznego” opus: transformują bezczasowe, pojetyczne dzieło sztuki na skutek prezentatywny i trazytywny, na przykład w trakcie wystawiania dramatu na scenie. Lausberg zauważa w końcu, że sztuka filmowa i nagraniowa najściślej zbliża sztuki praktyczne do pojetycznych ${ }^{15}$. W związku z przemianami świadomości twórczej właściwymi dla XX wieku, podobnie ma się sprawa, jeżeli chodzi o awangardowy wiersz - często, jak wiadomo, odwołujący się do technik filmowych. To wiersz procesualny, czynnościowy, którego treść pozostaje ekwiwalentna w stosunku do wykonania, podobnie jak w przypadku filmu - co nie wyklucza możliwości potraktowania awangardowego tekstu podobnie, jak potraktowalibyśmy zapis na taśmie filmowej, istniejący na niej po prostu, i przedtem, i po tym, kiedy zostaje dokonana projekcja filmu. Wiersz awangardowy byłby w ten sposób raczej dokumentacją artystycznych działań, precyzyjnie zapisanym scenariuszem działań raczej - niż tradycyjnie rozumianym wierszem. Bardzo taką koncepcję postrzegania nowocześnie rozumianej sztuki poetyckiej rozjaśnia Deleuzejańska formuła „obrazu-ruchu”, stosowana właśnie przede wszystkim w odniesieniu do kina, ale także wybrzmiewająca przy okazji filozoficznej refleksji nad sztuką literacką. Deleuze pisze:

\footnotetext{
${ }^{14} \mathrm{H}$. Lausberg, Retoryka literacka..., s. 23 i n.

${ }^{15}$ Tamże, s. 24
} 
Specyficznym materiałem pisarskim są słowa i syntaksa, syntaksa stworzona, która wznosi się nieodparcie w dziele i przenika do wrażeń. Ażeby wyjść poza percepcje przeżyte nie wystarczy, rzecz jasna, pamięć przywołująca jedynie stare percepcje ani pamięć mimowolna, która dodaje reminiscencję jako czynnik zachowujący teraźniejszość. Pamięć występuje w sztuce w niewielkim stopniu (nawet i przede wszystkim u Prousta). W rzeczywistości każde dzieło sztuki to pomnik, ale pomnik nie jest tutaj tym, co przywołuje przeszłość, lecz blokiem aktualnych wydarzeń, zawdzięczających utrwalenie wyłącznie samym sobie i nadających zdarzeniu połączenia, dzięki którym jest ono sławione. Działanie pomnika nie jest pamięcią, lecz fabulacją. Pisząc, nie wykorzystujemy wspomnień z dzieciństwa, ale dziecięce bloki, będące stawaniem-się-dziecka-teraźniejszego. Muzyka jest tym wypełniona. Nie potrzeba do tego pamięci, lecz złożonego materiału, który nie istnieje w pamięci, ale w słowach, w dźwiękach ${ }^{16}$.

Wiersz awangardowy nigdy nie jest wierszem gotowym, choć jest jednocześnie tekstem utrwalonym. Buduje swoje znaczenia poprzez zaburzanie porządków składniowych właśnie - dlatego trzeba go rozumieć czynnościowo, procesualnie - i owe porządki przechowuje, abyśmy mogli je zaktualizować; w sposób wolny, choć zgodnie ze sztuką.

\section{Składnia wiersza awangardowego}

Sławiński uwzględnia w swoim wywodzie pewne tezy dotyczące składni zdania awangardowego (metaforycznego, peryfrastycznego); składnia stanowi według badacza, jak mówi za Peiperem, przede wszystkim środek rozruchu znaczeń. Taka jednak reguła odniesiona zostaje przede wszystkim do Peiperowskiego zdania rozkwitającego, w którym kolejne elementy rozwijające wiersz rozumiane są jako „dopowiedzi”, obudowujące początkowe ujęcia dopełnieniami ${ }^{17}$. Aby było możliwe wdrożenie takiej lektury wiersza, która nie skupiałaby się tylko na peryfrastycznym charakterze Peiperowskich pseudonimów, ale umożliwiałaby uzasadnienie tego, dlaczego wiersz został skonstruowany za pomocą licznych powtórzeń i nawarstwień, jak właściwie odbywa się ów „rozruch znaczeń”, należałoby potraktować, jak proponowałam, całość awangardowego wiersza jako retoryczny okres bądź jako układ kilku takich okresów. Periodos, oznacza „bieg okrężny” wypowiedzi - w odróżnieniu na przykład od mowy ciągłej (oratio perpetua) o niesprecyzowanym celu. Na początku okresu pojawiają się zawsze rozproszone elementy wymagające uzupełnienia, które łączą się na końcu. Pierwsza część okresu, tworząca napięcie - określona zostaje w retoryce jako protasis; druga rozluźniająca jako apodosis. Brak wypełnienia oczekiwania rozluźnienia periodu traktowany jest jako błąd (vitium). Jeżeli językowego wyrażenia idei apodytycznej brak, wówczas mamy do czynienia z elliptikon schema. Działanie, które oparte jest na detrakcji powoduje, że druga części periodu określana jest jako anantapodosis. Jeżeli odejście od idei apodytycznej jest mniej oczywiste, np. brak jedynie odpowiedniego spójnika, więc apodosis jedynie odbiega od oczekiwań - pojawia się anakoloutos. Każdy okres retoryczny ma przy tym kolistą strukturę, na którą czasem składa się kilka

${ }^{16}$ G. Deleuze, P. Guattari, Co to jest filozofia?, przeł. P. Pieniążek, Gdańsk 2000, s. 185.

${ }^{17}$ Jak kontynuuje Sławiński: „Jej rozwój polegał na ciągłym nawracaniu do faz minionych, był więc zmiennością hamowaną przez niezmienność, przyrostem, któremu przeszkadzała identyczność powtarzanych elementów; początek i koniec zdania były nie tylko momentami przebiegu, ale także punktami granicznymi systemu: pomiędzy nimi [...] zawierał się szereg wariantów pośrednich”. J. Sławiński, Koncepcja języka poetyckiego..., s. 127-128. 
„systemów cyrkularnych”. Podstawowym przejawem wzajemnych relacji tych systemów jest najczęściej antyteza.

Z punktu widzenia związków słów w retoryce, w sferze elokucyjnej, wyróżnia się trzy typy figur $^{18}$ : przez przyłączenie (per adiectationem, czyli na przykład poprzez powtórzenie tych samych lub bliskoznacznych czy podobnie brzmiących słów, które można rozumieć jako różnego rodzaju tautologie, albo poprzez nagromadzenie, na przykład enumeracje, epitheton czy polisyndeton), odłączenie (per detractionem, w którym realizują się wszelkiego rodzaju elipsy, zeugmy z syllepsą, także asyndeton), poprzez sposób uporządkowania (per ordinem, jak anastrofa, hyperbaton czy różnego typu izokolony, więc upodobnienia członów retorycznych, wyrównanie ich liczby czy syntaktyczne uporządkowanie). Pamiętać przy tym warto, że tropy, figury słów i myśli nie stanowią osobnych światów; jest wiele zabiegów, które można reinterpretować, odnosząc się do ich sposobu działania ze względu na składnię czy ze względu na to, jaki stanowią typ operacji na słowniku. W końcu wiele figur myśli, rozumianych jako większe figury decydujące o porządku czy sposobie interpretacji całości dyskursu przez słuchaczy (dla ułatwienia można by je nazwać suprasegmentalnymi), traktowane mogą być także jako figury składni czy nawet tropy. Tak alegoria, synekdocha to jednocześnie tropy (i są tak traktowane w stylistyce), jak i figury kompozycyjne. W ten sposób jako figura myśli równorzędna wobec ironii interpretowana może być praeteritio (nazywana niekiedy paralepsą) lub reticentia (określana także jako aposjopeza). Pierwsza polega na retorycznej deklaracji pominięcia niektórych kwestii, druga na zamilknięciu, które to figury z punktu widzenia semantyki wypowiedzi mogą być postrzegane jako detrakcje, a składniowo niejednokrotnie są po prostu elipsami. Jeżeli chodzi o semantyczne figury myśli, na podobnej supragranicznej zasadzie działać będzie correctio, zakładające konieczność poprawienia myśli, poprzez powtórzenie części związku składniowego.

Najbardziej wyrazistymi środkami awangardowej składni, decydującymi o zgoła odmiennych strategiach twórczych, są wszelkiego rodzaju peryfrazy i elipsy. Te pierwsze, jako środki stylistyczne zakładające poszerzone omówienie opisywanego faktu czy zjawiska, jeśli chodzi o figury słów funkcjonują jako różnego rodzaju powtórzenia, więc tautologie, a także nagromadzenia, wzbogacane o przestawienia i poprawki. Inną strategię twórczą określają figury detrakcyjne, związane przede wszystkim z elipsą - rozbudowują tok wiersza przede wszystkim poprzez zeugmy, choć także zakładają przestawnie i korekcje. Detrakcyjna składnia zdania awangardowego typowa była przede wszystkim dla Przybosia, Brzękowskiego, do pewnego stopnia detrakcyjną spuściznę widać w wierszach Karpowicza, Miłobędzkiej, a z młodszych poetów na przykład w „awangardowych” wierszach Marcina Sendeckiego. Składnia związana częściowo z porządkiem cięcia i detrakcji, a częściowo polegająca na działaniach addytywnych, powtórzeniach i znaczących (konstrukcyjnie, nie słownikowo) tautologiach, wywodzi się bardziej z porządku wersologicznego zdania rozkwitającego Peipera. Taki porządek wydaje się później decydujący, jeśli chodzi o poezję Wirpszy, a współcześnie odnajduje się w wierszach Krzysztofa Siwczyka. Jeżeli przywołuję tutaj trzech, niejednokrotnie powracających w litera-

${ }^{18}$ Podaję za klasyfikacją Jerzego Ziomka, która stanowi swego rodzaju uproszczenie, w sensie porządkującego skrótu z klasyfikacji przytoczonej przez Lausberga (J. Ziomek, Retoryka opisowa, Wrocław 1990, s. 203-205). 
turoznawczych rozważaniach programotwórców historycznej awangardy (Peipera, Przybosia, Brzękowskiego), nie robię tego, by w ramach jakichś porządkujących linii wyłonić podążające ich tropem, zindywidualizowane projekty twórcze. Kierująca się konstruktywistycznymi przesłankami składni awangardowej Miłobędzka, budując swoje zdania na zasadzie detrakcji, czasami odwołuje się do takich figur składniowych, które powiązane byłyby z tradycją Peiperowską. Jeśli jednak rozwija pewne składniowe zabiegi zapoczątkowane przez Przybosia czy podane dalej przez Karpowicza, nie oznacza to, że jej poetykę można bezpośrednio wywodzić z sytuacyjnego, Przybosiowego projektu poezji. Awangardowa składnia po prostu żyje w poetyckiej tradycji, podobnie jak regularne metry wierszy poetów oświecenia czy romantyzmu. Jest poniekąd w podobnych eksperymentach upamiętniania, a jej konsekwencje konstrukcyjne mogą być wykorzystywane jako środki techne niezależnie od stopnia pokrewieństwa pomiędzy danymi twórczymi poetykami. Z tej perspektywy, w jakimś aspekcie, tropem składniowej tradycji Peiperowskiej (linii addytywno-tautologicznej), podąża wprawdzie Wirpsza - ale także zupełnie w innych rejonach poetyckich czujący się dobrze Piotr Sommer, którego postawangardzistą można by określić tylko w bardzo ściśle rozumianych warunkach. Składnia wiersza Sommera absorbuje przy tym w swoim obrębie działania przypominające zabiegi składniowe w wierszach nowoczesnych, amerykańskich, tłumaczonych przez niego poetów. Podsumowując: rewolucja, jaką w polskim wierszu spowodowała poetyka i program Awangardy Krakowskiej, której spuścizna znacząco wpłynęła na wszystkie właściwie interpretacje systemu (czy niesystemowości) wiersza wolnego w Polsce, w dużej mierze była właśnie rewolucją w obrębie składniowej konstrukcji zdania.

Chciałabym na koniec pokazać kilka możliwych realizacji tradycji addytywno-tautologicznej, w której zdanie tworzące wiersz jest zdaniem w ciągłym rozwoju, funkcjonującym w ramach okresu retorycznego (lub kilku takich okresów), budującym jednocześnie pewne konstrukty znaczeniowe o przestrzennym charakterze. Weźmy pod uwagę najpierw słynny wiersz Tadeusza Peipera Chorat robotników, pochodzący z tomu A, do którego autor w Nowych ustach odnosił się jako do wiersza-obsesji i źródła samego układu rozkwitania. O tym układzie Peiper pisał, jak przypomnę, właśnie w kategoriach związanych przede wszystkim z ruchem:

[...] przebieg widzeń odbywa się w ruchu błyskawicznym. Pod wpływem przybyłych widzeń poprzednie widzenia doznają natychmiastowych pomniejszeń, kawałkowań, przesunięć lub usunięć, a to wszystko staje się jeszcze terenem najazdu dla widzeń przybywających, które poruszają się galopem najeźdźcy. Zauważyć tu należy, że nie jest to ruch pochodzący z opisywania ruchu [...] Mamy tu ruch nie w świecie, lecz ruch międzysłowny ${ }^{19}$.

A oto sam wiersz:

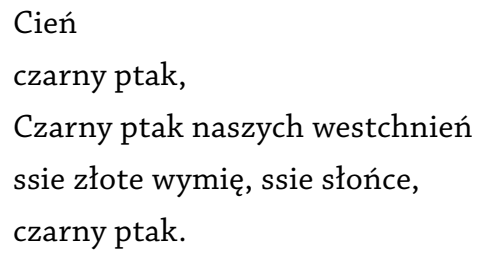

${ }^{19}$ T. Peiper, Tędy. Nowe usta, przedm. i kom. S. Jaworski, Kraków 1972, s. 301. 
Aaa, my chce my je mieć.

Mieć!

Mieć!

Złote wymię chce my mieć.

Nam twój śpiew,

nam złoty twój śpiew,

nam czarnym złoty twój śpiew,

twój śpiew rzeźbi nam świat,

nam świat

świat.

Patrzymy. Patrzymy? Kradniemy oczyma!

Kradniemy, kradniemy, kradniemy

oczyma.

Dym ma nóż,

ma nóż dym naszych westchnień,

ma nóż, kraje słońce na grosze i grosze rozdaje.

Dym ma nóż i kraje.

Wiersz Peipera przeczytany w porządku wersowym będzie miał charakter wypowiedzenia uporządkowanego poprzez anafory i epifory, rozumiane jako stylistyczne figury składniowe. Zasada rządząca powtórzeniami zostanie w ten sposób „unieruchomiona” i sprowadzona do roli wyznaczania poetyckich ekwiwalencji, podług reguł tradycyjnej analizy układu wersowego. Powtórzenia tak rozumiane będą jedynie wzmacniać nasze przekonanie o poetyckości podziału na wersy wobec braku normy metrycznej. Aplikowanie retorycznego aparatu do lektury figur składniowych nie wyklucza tej obserwacji, ale włącza ją jako porządkującą, początkową do poszerzonego systematu retorycznych rozważań, związanych z poetyckością całego zdania. Jeżeli mielibyśmy potraktować całość wiersza w kategoriach okresu retorycznego, musielibyśmy najpierw uznać, że mamy tu do czynienia z porządkiem kilku (trzech) okresów połączonych ze sobą swego rodzaju przejściem, które można potraktować jak wtrącenie - więc element właściwy dla mowy ciągłej (oratio perpetua), nie poddającej się kolistej zasadzie periodu. W retoryce, sztuce wymowy, zamiast o wersach, jak w poezji, mówimy o kolonach (i częściach składowych kolonów, czyli kommatach). Jeżeli chodzi o składnię zdania Peiperowskiego, podział na kommaty i kolony, odpowiadający porządkowi syntaktycznemu tu poniekąd w napięciu cedzonego, wyskandowywanego niemal zdania - czy też kilku zdań, które nie mogą w prawidłowy sposób się utworzyć - znacznie lepiej nadaje się do rozpatrywania porządku konstrukcyjnego wiersza. Będzie on miał więc oprócz delimitacji wersowej jeszcze inne, wewnątrz-wersowe delimitacje. Trzy Peiperowskie okresy z Chorału robotników opierają się na czterech kolejnych, mocno metaforycznych, rozwijających swoje sensy nawzajem wypowiedzeniach (przy czym ostatnia para stanowi wypowiedzenie rozwijające ten sam temat $\mathrm{w}$ dwóch wariantach): „Czarny ptak naszych westchnień ssie złote wymię” „Nam czarnym złoty twój śpiew

\footnotetext{
${ }^{20}$ Tegoż, Chorat robotników, w: idem, Pisma wybrane, Kraków 1979, s. 273-274. Numery nadane okresom zaznaczone przeze mnie.
} 
rzeźbi świat” „Dym ma nóż naszych westchnień” „Dym kraje słońce na grosze”. Wypowiedzenia te w wierszu Peipera doznają poniekąd zatrzymania w swoim biegu, a następnie dopiero rozwinięcia. Owo zatrzymanie (każdy z okresów można by przedstawić jako wyciągającą się po coś i cofającą przed czymś rękę) następuje w dwóch porządkach: wersowym i zdaniowym. Porządek rytmiczny, który nazwałam tu - występującym miejscami wyraźnie - skandowaniem, będący rytmizacją zmierzającą ku skandowaniu - stanowi wymiar towarzyszący dwóm poprzednim, niewątpliwie od niego ważniejszym. Wymiar rytmiczny można również postrzegać w podobny sposób, w kategoriach swoistego „podcinania zdań”: „Cień//czar/ny/ptak// czar/ny/ptak/na/szych/westch/nień" (podwójne ukośniki to granice wersów, wytłuszczona czcionka oznacza akcenty, przy czym można by jako akcentowaną potraktować także sylabę „ny”). Jeżeli chodzi o sposób, w jaki działają zdania w układzie trzech okresów - okres należałoby tu rozumieć bardzo prosto, jako zdanie pojedyncze rozwinięte, którą to możliwość retoryka daje. Różnicą pomiędzy retorycznym okresem a liniową, określoną przez Lausberga jako bezkształtna oratio perpetua, pozostaje, jak mówiłam, jego „kolistość”: porządek polegający na tym, że na początku periodu pojawiają się myśli niepełne, które wymagają integracji. Zwykłe niewypełnienie idei tworzącej napięcie, pierwszej części periodu (protasis), określane jest mianem detrakcji, noszącej specjalną nazwę (anantopodosis). W tym sensie rozwijanie się zdań w trzech okresach zostaje do pewnego, granicznego stopnia, stanowiącego swoisty klimaks składni, rozpędzone, a następnie ulega z powrotem ściągnięciu. Zauważyć przy tym należy, że w całości Chorał się jednak rozwija i jego wariantywna puenta pozostaje w końcu otwarta. Uzupełnianie poszczególnych kommat, tworzących kolony, odbywa się na zasadzie zgodnej ze składniowym rozbiorem zdania: od podstawowych związków grupy podmiotu, logicznego początku zdania, uszczegółowianego o kolejne grupy dookreślające podmiot i dopełnienie, przechodzimy do grupy orzeczenia, znowu uszczegółowiając informację dotyczącą całości. Dzieje się to również na specyficznej, wielokrotnej, „ciętej” zasadzie. W ten sposób na przykład całość strofy środkowej, drugiego okresu, moglibyśmy zapisać następująco: „Nam twój śpiew,//nam/czarnym złoty/twój śpiew,//twój śpiew/rzeźbi/nam świat//nam świat//świat". Rozdział na człony zostaje tu wprowadzony zgodnie z porządkiem tworzenia napięcia i rozluźnienia go poprzez rozwiązanie; rozwiązania te jednak w drugiej części zdania nie rozwijają go już, ale ściągają z powrotem do jednego, znów wyskandowanego słowa. Przy bardzo wolnej, "ciętej” lekturze nowe elementy zdania funkcjonują w nim jak wtrącenia (jako hyperbaton czy też parenteza, zależy na jakim piętrze kompozycji je przeinterpretujemy) - co wydaje się dziwne, zwłaszcza kiedy zostaniemy zmuszeni do pomyślenia w takich kategoriach o orzeczeniu („rzeźbi”). W ten sposób zobaczyć można, w jaki sposób tok zdania rozwija się poprzez powtórzenia, więc anadiplozę w funkcji correctio („złoty twój śpiew// twój śpiew rzeźbi nam świat”). Zdanie jednocześnie zostaje zamknięte w kole poprzez gest bliski epanadiplozie („Nam twój śpiew... nam świat"). Parentezy, konieczne, bo rozbudowujące sensy wypowiedzeń, funkcjonują więc jako swego rodzaju wypustki, wyciągnięcia zdania ku granicy drugiego powtórzenia („nam świat/nam świat”), po to, by potem dokonać rozwiniętych sensów detrakcji. Wiersz Peipera zatytułowany Chorał robotników jest wprost nabrzmiały głodem i pożądaniem, pulsuje czy też wyciąga się - właśnie ze względu na gest rozbudowywania i ściągania zdań - w retorycznej figurze, którą można by tu określić mianem anantopodonu. Zwróciłam tu uwagę na jedynie nieznaczny element gry składniowej, którą należałoby uwzględnić przy interpretacji całości Chorału; pozostają jeszcze współbrzmienia, zagadnienie chiazmu, który prawie ujawnia się w trzecim okresie, tworząc w nim swoisty klimaks, kwestia rymów homonimicznych 
w tym wierszu, rozmaitych współbrzmień, paronomazji, które znowu można rozumieć w kategoriach instrumentacji głoskowej lub retorycznych powtórzeń. Wiersz Peipera, w którym wyznaczenie retorycznie rozumianych rozdziałów, uwidaczniających sferę konstruktorskich dyspozycji tekstu (na płaszczyźnie elokucji odpowiadających sferze kompozycji), powoduje, że uzyskujemy jeszcze jedną warstwę, czy też jeszcze jeden wymiar czytania poetyckich zdań - warstwę „budowy/wykonywania” tekstu, uniezależnioną od normatywnych sensów składni, wobec których metaforycznie opowiada się wiersz, budującą inne napięcie niż podziały wersowe, tnące składnię normatywnie rozumianych zdań. Retoryka, determinowana także przez wiedzę o składni, pozwala badać operacje poetyckie na zdaniu uwolnionym ze składniowej normy, typowej dla zdania prozatorskiego. Umożliwia badanie swoistej rekonstrukcji składniowej na przestrzeni „całego zdania”, składającego się na okres retoryczny - o poetyckim charakterze. Niewątpliwe składnia „działająca” w takim sensie determinuje odbiorcę, by traktował wiersz nie w kategoriach gotowej propozycji estetycznej czy poznawczej, czytelnej w odniesieniu do codziennej normy komunikacji, ale by zaangażował się raczej w rekonstruowanie wiersza jako swoistego procesu. Wiersz awangardowy byłby wierszem „ruchomym” niczym niemy film, co pozostawałoby zgodne z politycznym wzmocnieniem jego dydaktycznych i perswazyjnych funkcji, powiązanej z performatywnym aspektem sztuki wymowy.

Oczywiście składniowe zdobycze awangardy nie muszą mieć takiego właśnie, perswazyjnego czy dydaktycznego charakteru. Mocna obecność „działań” składniowych w nowej polskiej poezji pozostaje ze spadkiem awangardowym jakoś związana, choć najczęściej jej możliwe koneksje $\mathrm{z}$ retoryką wynikałyby $\mathrm{w}$ ogóle $\mathrm{z}$ formuły wiersza wolnego, uruchamiającego $\mathrm{w}$ poezji rytm i składnię zwykłego, najczęściej mówionego zdania. W taki sposób daleką realizacją strategii addytywno-tautologicznej w poezji pozostają niektóre wiersze Piotra Sommera. Weźmy pod uwagę wiersz Wczoraj z Piosenki pasterskiej:

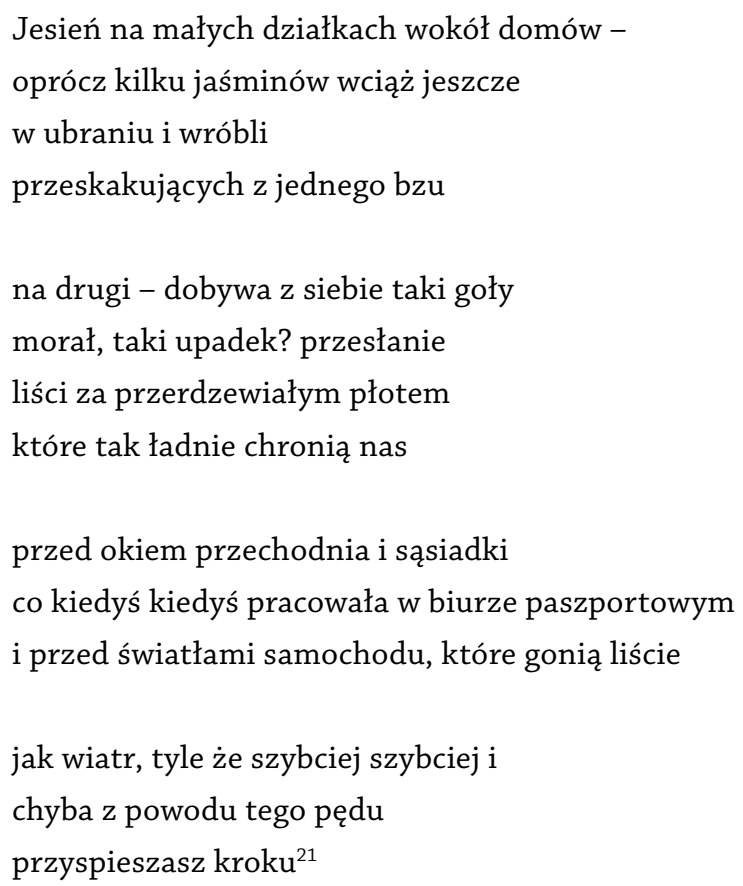

${ }^{21}$ P. Sommer, Po ciemku też, Poznań 2013, s. 246. 
Wiersz Sommera, podobnie jak wiersz Peipera, traktuje o składni „rozwijającej”, przy czym na środki składniowe, związane z zabiegami konstrukcyjnymi (dyspozycyjno-kompozycyjnymi), nakłada się jeszcze kilka innych warstw kompozycji słów i znaczeń, związanych z innymi interesami. Niewątpliwie ważny systemat podziałów wewnątrz wiersza utworzy zarówno sonet (jako mały gatunek poetycki) z jego dwudzielną budową, jak i intonacyjny kontur wersów i znaczenia przerzutni, połączone ze składnią rozumianą jako czynnik wersyfikacyjny. Wczoraj złożone jest z dwóch kolonów (dwóch zdań, stanowiących elementy jednego okresu), uporządkowanych w zgodzie $z$ hierarchią rozwijania pojęć - od mniej dyskursywnie skomplikowanych, odnoszących się wprost do jesieni, stanowiących swego rodzaju metaforyczny do niej komentarz, do bardziej konceptualnych, umożliwiających nawet w końcu opowiedzenie pewnej historii. Uporządkowanie intonacyjno-składniowe, rozumiane tu jako czynnik wersyfikacyjny, idzie o lepsze z rozwojem całego okresu, który wprowadza pomiędzy wersy własne, dodatkowe cięcia. Pierwsze zdanie, które stanowi dla nas początek (protasis), zostaje spuentowane w drugiej strofie, wyznaczając w niej mocny rozdział znakiem zapytania. Ten rozdział zastępuje poniekąd tradycyjne rozróżnienie części przedstawiającej i refleksyjnej wewnątrz sonetu. Rozluźnienie napięcia, zawiązanego poprzez początek (w formie kommaty): „Jesień na małych działkach wokół domów - ” w formule „dobywa z siebie taki goły/morał, taki upadek?”, odbywa się poprzez wypełnienie zobowiązania okresu w sposób pozorny, urywając myśl poprzez wyrażenie wątpliwości - i stwarzając jednocześnie przestrzeń dla nowego rozwinięcia. Pauzy wprowadzające wtrącenie to dodatkowe działy wewnątrz kolonu (pierwszy kończy się wraz z wersem, tworząc coś w rodzaju supermocnej, bo uwidocznionej pauzy), drugi rozdziela pierwszy wers drugiej strofy, utrudniając przy tym dodatkowo śledzenie sensu całości zdania. Co typowe dla Sommera, wersy i przerzutnie szatkują długie wypowiedzenia, złożone tak, jakby były wypowiedziami typowymi dla oratio perpetua, ciągłymi, niekoniecznie zmierzającymi do określonego celu. Wszelkie naddane zabiegi składniowe pozostają więc niejako ukryte. Jako kontynuację wypowiedzi „o jesieni” potraktujemy początkowo wers drugi: „oprócz kilku jaśminów wciąż jeszcze/w ubraniu". Całość rozwinięcia zmierzającego ku puencie zdania pozostaje także urwana, czy też rozwija się w fałszywy sposób, ku równoważnikowi, poprzez dwa określenia, okoliczników sposobu lub okolicznika i przydawki określającej podmiot. Rozwinięcie rozpoczynającej kommaty sugeruje, że „w ubraniu” mogą być zarówno jaśminy, jak i sama jesień. Wprowadzenie równorzędnego członu: „i wróbli/przeskakujących z jednego bzu//na drugi”, może tu w konsekwencji sugerować nawet, że „jesień jest jeszcze w ubraniu” oprócz jaśminów i także wróbli - przy czym, jeżeli chodzi o tok logiczny zdania - zbudowane by było ono na zasadzie hyperbatonu, kiedy „wciąż jeszcze w ubraniu” byłoby członem rozbijającym poprawną kolejność słów w pełnym wypowiedzeniu, w którym człony wyliczenia powinny znaleźć się koło siebie. W ten sposób śledzony wątek także się urywa, kiedy w kolejnej strofie odkrywamy kolejną pauzę, wyznaczającą koniec parentezy - i tym samym spostrzegamy swój błąd. Niemożliwe, żeby zarówno jesień, jak i jaśminy i wróble (połączone z nią i tak na anakolutycznej, potocznej zasadzie z „oprócz” w funkcji „i”), dobywały z siebie wszystkie „taki goły morał” - taka możliwość byłaby czysto komiczna. Parenteza zbudowana została raczej z dwóch paralelnych wypowiedzeń („jaśminów wciąż jeszcze w ubraniu” i „wróbli przeskakujących") o charakterze grup okolicznikowych w funkcji przydawki, jeśli odniesiemy je do jesieni; lub w funkcji rozbudowanego dopełnienia równorzędnego wobec dobywanego przez „jesień” z siebie, znacznie później „gołego morału”. Jeżeli „jesień” nie byłaby jednak „wciąż jeszcze w ubraniu” - za to „oprócz kilku jaśminów i wróbli” dobywałaby z siebie „taki goły 
morał, taki upadek?", mielibyśmy tu do czynienia z wtrąceniem, które jest także inwersją. Sommer buduje w tym miejscu wiersz na zasadzie swego rodzaju fałszywego wzmagania i rozpraszania sensów; składnia jest permanentnie dwuznaczna, amfiboliczna. To, co pełni funkcję swoistego nagromadzenia, rozbudowanego pola określeń podmiotu, okazuje się możliwym dalszym ciągiem, przestawionym tylko - jakby mówiący wybiegł naprzód myślą, a potem chciał wrócić do tematu. Taką figurę słowa określić można jako rozbudowaną prolepsę, uprzedzenie dalszego ciągu zdania rozumianego jako zdarzenie. Na końcu długiego, powolnego zwlekania z puentą, swego rodzaju składniowej antycypacji czy retardacji, pozostawalibyśmy $z$ aporią. Sens zdań, poprzez poszczególne „podcięcia” (logiczne i wersowe, wynikające z pauz i przerzutni z jednej strony, a z drugiej z zabiegów składniowo-retorycznych), jest w wierszu Wczoraj niejako podważany i rozmywany z wersu na wers raczej niż sumowany i ujmowany w tradycyjnie rozumiane okresy. Powiedzieć można, zapowiada od razu składniowym ruchem znaczenia liści rozwiewanych przez wiatr, które pojawiają się w puencie. Tak też fragment podkreślony poprzez powtórzenie o charakterze anadiplozy z correctio („taki goły/morał, taki upadek?") może być z punktu widzenia figury myśli interpretowany jako apozjopeza czy dubitatio, a z punktu widzenia kompozycji będzie wypełnieniem oczekiwania rozluźnienia okresu odbiegającym od oczekiwań odbiorcy (zamiast dopowiedzi w sprawie „jesieni na małych działkach” uzyskujemy pytanie, wątpliwość, jak sugeruje słowo „goły”, podszyte być może rozczarowaniem). Poprzez szczególnego rodzaju rozluźnienie $\mathrm{w}$ obrębie składni, spowodowane błędną logiką rozwijania części zdań tworzących kolony i okresy, w dwóch pierwszych strofach uzyskujemy splot dwóch antytetycznych „linii” wypowiedzi, które zyskują jednak swoje podsumowanie w części drugiej. Powiedzieć można, że wymieniają się one znaczeniami - że cyrkuluje ono między nimi, właśnie tak jak w retorycznym okresie. Druga część powinna więc przynieść oczekiwane rozluźnienie. Okazuje się niestety, że także w niej zdania Sommera są niejako "podkręcane” - sugerując swoją niby to potoczną, a w rzeczywistości pokrętną logiką zdążanie do określonego sensu (apodosis), ale oczekiwanie to jedynie pozornie, pretekstowo - więc anakolutycznie. Składniowe porządki poddane są zasadzie swoistego narastania sensów, poprzez pozornie logiczne ich doprecyzowywanie. To doprecyzowywanie prowadzi nieuchronnie nie do wyjaśnień, a do pytań i rozproszeń. Kolejny okres wiersza Wczoraj jest również całym zdaniem, skrupulatnie pociętym przez uwieloznaczniające składnię przerzutnie; jego całość opisać można by było jako epanadiplozę z rozbudowaną korekcją, przechodzącą w zawieszenie głosu właściwe dla apozjopezy. Druga część powtarza więc składniowo-retoryczną zasadę pierwszej, tyle że w mocniejszy sposób podkreśla swoją kolistość: „przesłanie/ liści za przerdzewiałym płotem...” prowadzi nas do świateł samochodu, „które gonią liście// jak wiatr". Początkowa antyteza dwóch idących o lepsze składniowych wątków zakończona zostaje paradoksem - podkreślonym powtórzeniem tego samego znaczenia na granicach okresu. Może być ono tylko homonimiczne (liście za płotem, chroniące nas ładnie przed okiem sąsiada, nie muszą być tymi samymi liśćmi, które pędzą przed sobą światła samochodu). A jednak składniowo zdanie jest właśnie wewnętrznie sprzeczne i dwuznaczne. Środek tego, co okala epanadiploza, to szereg wyliczeń, więc figura nagromadzenia („liście” chronią nas „przed okiem przechodnia” i „sąsiadki” i „przed światłami samochodu”), którą można potraktować jako polisyndeton, łączący spójnikiem „”” wiele dopełnień. Składnia jest tu prostsza niż w pierwszym kolonie, jednak poprzez paradoksalny element „liści”, pojawiających się raz jako jeszcze „chroniące nas przed okiem przechodniów”, a raz jako „pędzone [po drodze] światłami samochodu", zdanie zostaje związane na zasadzie powtarzającej efekt wcześniejszej antytezy, 
tylko w poniekąd skrócony sposób, w wypowiedzeniu, które jest po prostu wewnętrznie sprzeczne, kontrlogiczne. Liście jednocześnie „chroniąc nas” i „będąc pędzone”, więc nie chroniąc przed okiem przechodniów i światłami samochodu, są liśćmi, które jeszcze pokrywają dość gęsto otaczający działkę szpaler i takimi, które już opadły. Prowadzi nas to ku ostatecznemu rozluźnieniu puenty wiersza, który znowu - anakolutycznie - zamiast cokolwiek wyjaśniać, najpierw rozpędza się poprzez zwykłe, ekspresywne powtórzenie („tyle że szybciej, szybciej") i poprzez spójnik (wersyfikacyjnie zawieszający głos, niby przed wyjawieniem tajemnicy) wiedzie nas ku prostemu oznajmieniu, które niczego nie wyjaśnia, stanowiąc raczej kolejny element układanki. Być może pojawia się w ten sposób podmiotowa formuła mówiącego w wierszu: „i/chyba z powodu tego pędu/przyspieszasz kroku”, ku któremu nieuchronnie zmierzałby ten „składniowo-liściowy” zamęt. Wczoraj - pomimo swego czasu przeszłego bardzo mocno ten pełen niepokoju moment uprzytamnia, przy czym zabiegi składniowe wydają się bardzo skrupulatną notacją - pamięci ruchu. Jeżeli przyjmiemy tę perspektywę, w punkcie dojścia będziemy musieli zmierzyć się z sugestią, że także mówiący jest jednocześnie "wewnątrz", na działkach, po stronie statycznie przedstawianej jesieni - i "goni” ulicą, razem $\mathrm{z}$ liśćmi, przed światłami samochodu. W ten sposób składnia całości tekstu pozostawałaby do uzgodnienia z pamięcią początkowo wolniejszych, a później bez wyraźnego powodu przyspieszanych kroków, czego powód próbuje się nam zarazem precyzyjnie, jak i niezgrabnie przybliżyć. 


\title{
SEOWA KLUCZOWE:
}

\section{performatywność}

\section{awangarda}

\begin{abstract}
ABSTRAKT:
Pytanie, jakie chciałam w moich wersyfikacyjnych rozważaniach postawić, w punkcie wyjścia dotyczy nie tylko i nie tyle składni zdania awangardowego. Zasadza się ono raczej na próbie zmierzenia się z płaskością kartki papieru - z czym powiązana byłaby intuicja możliwej przestrzenności i ruchomości układów składniowych - której próbowali dopracować się awangardziści, stawiając wobec swoich wierszy postulaty „budowy”. Taką możliwość stworzyć może retoryka, jeżeli retoryczne przesłanki kompozycji dzieła (chcę je rozumieć raczej jako „działanie”), wykorzystane zostaną nie tyle jako narzędzia opisujące stylistyczne aspekty tekstu, ale jako systemat twórczych dyspozycji, powiązanych z odbiorem, traktowanym w kategoriach actio - wykonywania tekstu artystycznego. Tekst poetycki w takim ujęciu byłby „notacją” - na podobieństwo zapisu nutowego w muzyce - jego „wykonanie” polegałoby zaś na „mimetycznym” powtórzeniu czynności twórczych autora.
\end{abstract}




\section{WIERSZ WOLNY}

\section{p o e t y k a}

\section{r e t o r y k a}

\section{NOTA O AUTORZE:}

Joanna Orska - krytyczka, literaturoznawczyni. Pracuje w Instytucie Filologii Polskiej Uniwersytetu Wrocławskiego w Zakładzie Literatury Polskiej po 1918 roku, gdzie prowadzi m.in. warsztaty krytyczne i zajęcia $z$ najnowszej literatury. Swoje recenzje i szkice krytyczne publikowała w wielu czasopismach społeczno-kulturalnych i naukowych (m.in. „Teksty Drugie”, „FA-art”, „Odra”). Autorka książek: Przełom awangardowy $w$ dwudziestowiecznym modernizmie $w$ Polsce; Liryczne narracje. Nowe tendencje w poezji polskiej 1989-2006; Republika poetów. Poetyckość i polityczność w krytycznej praktyce. Mieszka we Wrocławiu. 